\title{
Can Anything Philosophical Come out of Darwinism? Resolving the Conflict between Evolutionary Biology and Philosophy in the Twentieth Century
}

\author{
Uche S. Odozor \& Emmanuel O. Akintona \\ http://dx.doi.org/10.4314/ujah.v22i2.10
}

\section{Abstract}

Is the idea of 'evolutionary philosophy' well taken? If it is, how does evolutionary biology bear on philosophy? The incursion of biological science into ethics towards the end of the 19th century elicited a widespread reaction from twentieth century philosophers, who instantly began to question the relevance of Darwin's work to philosophy. The doctrine of natural selection may not have comprehensively resolved the age-old problems of philosophy, for example, in the area of human morality and ethical thinking; in fact, it may not be able to replace philosophical inquiry in the absolute sense advocated by most evolutionary theorists. But it has made some remarkable contributions towards a better appreciation of philosophical problems. To this end, this paper explored the various areas of mutual interest between evolutionary science and philosophical inquiry. It highlights the tacit affinities between the two, and thus, finds that even from inception evolutionary biology has tended to follow philosophical inquiry rather closely in the different issues that have been of interest to the latter since its early beginnings in ancient Greece. Some of the areas of mutual concern and interest between the two fields of inquiry include the discourse on God, human nature, the universe, life, ethics, and politics. The paper, therefore, concluded with the submission that evolutionary biology and philosophy complement, rather than oppose, each other. Ultimately, such complementation suggests that both 
disciplines have a future together; among other things, it makes possible the idea of 'evolutionary philosophy'.

\section{Keywords: Darwin; Evolutionary Biology; Naturalism; Philosophy; Science}

\section{Introduction}

The connection of biology to ethics dates back to Aristotle (Boniolo and De Anna 2006). But interest in this connection only began to bloom towards the end of the nineteenth century, when Charles Darwin made his entry. Following that, an overarching debate on evolution and ethics has focused on the very relevance of Darwin's theory for philosophy in general. Relying on the assumption that philosophy is, to a very considerable extent, metaphysical and normative in nature, and speculative in method, while science particularly biological science - is basically descriptive, philosophers, at the turn of the twentieth century, variously maintained that, in itself, Darwin's theory has very little to offer philosophy. Notable among these philosophers were Ludwig Wittgenstein, Henry Sidgwick, G.E. Moore and Bertrand Russell, as well as the prominent evolutionary biologist, Thomas H. Huxley, a contemporary of Darwin.

Prior to the advent of evolutionary biology, moral discourse had been confined to the domain of philosophy, where it focused on the analysis of morality and its demands on humans as beings sharing a social space (Rachels 2003, p.1). This epoch, which is now regarded as the era of traditional ethics, ranges from Socrates, through Immanuel Kant, to John Rawls, and excludes David Hume and, perhaps, the Pragmatists. The traditionalists took (human) biology for granted in their approach. For them, morality was, basically, an ideal to which humans not only must aspire, but also 
cultivate, as a matter of obligation. Unlike the biology-based ethicists, they located morality beyond the human physiological constitution or biological make-up, but not outside of human affairs, contrary to the transcendentalist charge often levelled at them in contemporary ethical inquiry. Since their aim had been to discover a plausible theory of the ideal society where humans may actualise their potentials and live a happy life, ethics became, for them, somewhat intricately connected with the best possible social and political arrangement that would make that happy state of affairs attainable. The traditional approach, therefore, differs from the biological approach to ethics, which views morality as an adaptive trait of living organisms in their ecosystem, and views ethics as the natural history of the survival of biological organisms from some distant, primeval past (Ruse and Richards, 2017).

In this paper, however, our aim is to explore, and delineate, the close affinities shared by (evolutionary) biology and philosophy. These affinities demonstrate that evolutionary biology complements philosophy rather than undermines it. Also, they highlight the ways in which the synthesis of both approaches can inform an 'evolutionary philosophy'.

\section{On the Relevance of Biology to Philosophy and Ethics}

Since Aristotle, Charles Darwin's work on biology and morality, On the Descent of Man and Selection in Relation to Sex, which was published in 1871, marked the official beginning of the outright incursion of biological science into ethical inquiry. Towards the turn of that century, however, philosophers began to raise salient questions concerning the relevance of Darwin's theory of natural selection not only to ethics, but also to philosophy in general. This is apparently because Darwin was able to level up his ideas to the 
acceptable standards of natural science. The objection first came from some prominent evolutionary biologists themselves, though unwittingly. Huxley $(1898$, p.80), for instance, criticising Spencer's ambitious project of deriving moral principles from stark evolutionary process, dismissively retorted:

Cosmic evolution may teach us how the good and the evil tendencies of man may have come about; but, in itself, it is incompetent to furnish any better reason why what we call good is preferable to what we call evil than we had before.

Thus, Huxley apparently did not believe that evolution, as a biological theory, could do any more for moral theory than philosophers had done before prior to the advent of evolutional thinking. So, Huxley (1898, p.79) settled for "evolution of ethics," rather than the controversial "ethics of evolution," while submitting that Darwin's theory only served to explain the origin of moral sentiments, and not, as Spencer had held, to guide human moral action. It will be recalled that up to the era in which Huxley - and, of course, Darwin - had been writing, moral discourse had been in the domain of philosophy and theology.

On the philosophical side, Wittgenstein $(1923,4.1122)$, for instance, seemed to find no problem with the notion of separating biology and ethics, when, merely three decades later, he categorically and succinctly stated that "the Darwinian theory has no more to do with philosophy than has any other hypothesis of natural science."

Moore (1966, p.10; original emphasis) expressly endorsed Wittgenstein's submission as follows:

[E]veryone would agree with Wittgenstein that Darwin's Theory of the Origin of Species, including 
man, has nothing more to do with philosophy than any other hypothesis of Natural Science: and that whatever it may have to do with it, it's not the business of philosophy to discuss whether it's true or not.

Though Moore offered some detailed argumentation for this view, he said rather little about why this may be generalised to all of philosophy. As Cunnigham (1996) aptly noted, Moore was apparently influenced by his mentor, Henry Sidgwick, of whom Jerome Schneewind (1977, p.385; cited in Cunningham, 1996, p.55) wrote:

Cautious willingness to accept the hypothesis of evolution by means of natural selection as a valuable scientific theory, coupled with scepticism as to its bearing on philosophy in general and on ethics in particular, characterized Sidgwick's attitude throughout his life.

Russell (1914, p.26) also substantively espoused the same outlook, arguing that:

What biology has rendered probable is that the diverse species arose by adaptation from a less differentiated ancestry. This fact is in itself exceedingly interesting, but it is not the kind of fact from which philosophical consequences follow. Philosophy is general, and takes an impartial interest in all that exists. The changes suffered by minute portions of matter on the earth's surface are very important to us as active sentient beings; but to us as philosophers they have no greater 
interest than other changes in portions of matter elsewhere.

Cunningham (1996) noted that Russell's objectionaccordingly expressed in this passage - to biology, and to evolutionary biology in particular, is that they are not sufficiently general to merit philosophical consideration. So, Russell's point seems to be that philosophy, by its very nature, concerns itself only with theories that govern everything that exists. Since biological theories apparently do not meet this criterion, they could not be relevant to philosophy.

\section{The Evolution Hypothesis and its Development}

The choice of Charles Darwin as the starting point of this discussion is informed by three reasons: first, by identifying 'natural selection' as being behind the evolutionary process, Darwin has brought subtlety to evolutional thinking. This made his work to be the first comprehensive formulation of the evolutionary hypothesis, even though the hypothesis did not originate from him. Second, the vast majority of subsequent evolutionary theorists, to the present, have been unanimous in endorsing Darwin's contributions, not only as the best logical formulation of the theory, but also as the most scientifically developed. For instance, the evolutionary approach to ethical inquiry, which is currently making waves in Western scholarship as 'biologicised ethics', has been directly derived from Darwin's thesis of natural selection, and has continued to look to Darwin for further guidance and illumination on its areas of difficulty and uncertainty. Third, Darwin made the first attempt to render an account of the origin and nature of morality from the point of view of natural science, morality and ethics being, as was said earlier, originally confined to the domain of philosophy. 
Darwin seemed to have a very conscientious temperament. His thesis of natural selection had been considerably developed by 1838, following his return from the naturalist voyage to the Galápagos Islands of South America on board the Beagle. Yet he would not publish his findings - apparently out of fear of public outrage - until twenty years later, after he realised that another young naturalist, Alfred Wallace, had also independently reached the same conclusions (Quammen 2004; Browne, 2018). Darwin finally took to the press and got the first edition of On the Origin of Species published in 1859.

Back in 1838 Darwin had read Thomas Malthus' Essay on the Principle of Population (1789), in which the Christian minister and political economist, considered it inevitable that human population growth would, with time, tend to outstrip available natural resources. According to the Malthusian model of economic analysis, human population tended to increase geometrically (2:4:8:16), whereas food supply followed it only in arithmetic ratio (2:4:6:8). This meant that while the population increased by doubling its original number, food supply merely followed suit in simple arithmetic progression (Lewens 2007, p.42). Based on this, Malthus projected that food production would, in time, necessarily fail to catch up with the number of individuals being born into each generation. Darwin, on his own part, generalised this principle to all organic life, since it is not only humans that tend to overreproduce. Among animals and plants, reproduction also runs ahead of available natural resources, thereby leading to a fierce competition. In acknowledgment of Malthus' influence, Darwin (1859/1872, chapter three) referred to the principle of natural selection as 'the doctrine of Malthus, applied to the whole animal and vegetable kingdoms'. 
Darwin called attention to a marvelous destruction of life happening in nature, which is necessary for the propagation of life. The struggle for existence is characterised by awesome competition for survival; a phenomenon culminating in 'natural selection', wherein newly evolving conditions favour 'the fittest'; that is, those individuals of a given species 'most suitable for the conditions' or best adapted to prevailing conditions in the cosmos (Browne, 2018, p.16). In this process of selection, Darwin explained that nature basically adopts the same method as does a human animal breeder, who would usually artificially breed from his best stock, to continue producing the finest offspring from his herd. This principle became, for Darwin, the mechanism which actually drives evolution; and the theoretical gap in the works of earlier evolutionists, such as Jean-Baptiste Lamarck, was filled.

With their 'selective advantage', only these individuals, as Darwin argued, survive the next phase of the cosmic process of evolution or development. Although the struggle for existence gives rise to divergent species after several generations, the resultant varieties may fare better or worse, depending on the state of the cosmos at each point in time, as Huxley $(1859$, p.147) would later elaborate:

Every variety to which a species may give rise is either worse or better adapted to surrounding circumstances than its parent. If worse, it cannot maintain itself against death, and speedily vanishes again. But if better adapted, it must, sooner or later, "improve" its progenitor from the face of the earth, and take its place. If circumstances change, the victor will be similarly supplanted by its own progeny; and thus, by the operation of natural causes, unlimited modification may in the lapse of long ages occur. 
While the organisms whose modes of adaptation are favoured survive, thrive and pass on their traits to the next generation, the ill-adapted species simply perish because they do not possess the requisite survival traits or characteristics. This is 'survival of the fittest', a term actually coined by Herbert Spencer (Flew 1967, p.13; Holmes and Livingstone, 2021, p.3). However, this process does not always entail competitive violence among species. For instance, it has been speculated that a sudden increase in the gravitational pull in the earth, at some point in the course of the cosmic process, made it impossible for the dinosaurs and pterodactyls - allegedly massive animals - to manage their weight; and so, they gradually got phased out (Shkolenko 1987, p.50; Kingston 2004; Choi 2007).

Darwin's findings naturally unsettled the intellectual community; for if natural selection does, in fact, happen as the consequence of random variation in living organisms, giving impetus to macroevolution, then it would be virtually untenable to maintain that species are immutable, or individually created. As such, the doctrine of essentialism in philosophy-which was, for the most part, taken for granted in the Western intellectual tradition — would be false.

\section{The Evolution of (human) Moral Sense}

Thus far, Darwin's account had concentrated on plants and the other animal species, and said rather little about humans. In The Origin, Darwin expounds his theory, incorporating all living matter-animal and plant-in a sweeping generalisation that attempts to proffer a biological explanation for the age-old philosophical problem of 'The One and the Many' (Lacey, 1976, p.227). Although the work, up to this point, has largely refrained 
from discussing the human species, attentive reading would discern the underlying tacit suggestion that the human species is a part of the natural order, which, according to Huxley (1896, p.p.202), 'denotes the sum of the phenomenal world, of that which has been, and is, and will be'.

At this point in the history of thought, the prevailing assumption among philosophers and theologians was that the human species reserved some distinctness from other aspects of the natural world due to the attributes of rationality, intelligence, and the capability for morality. But Darwin (1871, p.1) broke his silence on the human species, announcing that "Light will be thrown on the origin of man and his history'. In his next book, The Descent of Man and Selection in Relation to Sex (1871), Darwin (1871, p.609) turned to the human species, arguing not only that humans descended from 'a less highly organised form, ... a hairy, tailed quadruped, probably arboreal in its habits, and an inhabitant of the Old World', but also that the human moral sense or faculty evolved by natural selection through the development of 'social instincts'.

For Darwin (1871, p.155-156), these instincts include such feelings and dispositions which 'impel ... animals to live in a body'; make them feel 'uneasy when separated from their comrades, for whom they would have felt some degree of love'; and which enabled them to '[warn] each other of danger, and ... [give] mutual aid in attack or defence'. Darwin (p.156) continues:

All this implies ... sympathy, fidelity, and courage. Such social qualities ... were no doubt acquired by the progenitors of man ... through natural selection, aided by inherited habit.... A tribe possessing the above qualities would spread and be victorious over other tribes.... Thus, the social and moral qualities would 
Odozor and Akintona: Can Anything Philosophical Come out of Darwinism?

tend slowly to advance and be diffused throughout the world.

The ability to reflect on past actions engendered the ability to feel remorse for omissions or commissions; due to the premium placed on the praise or blame of comrades, individuals would tend to avoid conducts leading to disapproval, while doing only those things that would earn them glory and respect. Thus, in this development of sympathy, courage, fidelity and conscience, each one came to realise from experience that if he aided his fellowmen, he would commonly receive aid in return; and, more importantly, that his own self-interest is also better advanced by protecting that of the group, through cooperation. Darwin (p.156) submitted that, "A tribe rich in the above qualities would spread and be victorious over other tribes," and, thus, be naturally selected in the struggle for life. For Darwin, the evolution of morality was, therefore, the evolution of human conscience.

The appeal to 'group selection' is probably most prominent in his discussion of the origins of the moral sense, because, according to Darwin, it takes the development of an altruistic consciousness in a species for morality to evolve. This altruistic consciousness is primarily developed when animals find themselves in a 'predator-prey' situation, because that is the situation in which they are typically moved to protect others, in such a way as to sometimes lay down their own lives. But how exactly does group selection drive moral evolution? Darwin (pp.159-160) further explains:

[A] tribe including many members who, from possessing in a high degree the spirit of patriotism, fidelity, obedience, courage, and sympathy, were 
always ready to give aid to each other and to sacrifice themselves for the common good, would be victorious over most other tribes, and this would be natural selection. At all times throughout the world tribes have supplanted other tribes; and as morality is one important element in their success, the standard of morality and the number of well-endowed men will thus everywhere tend to rise and increase.

Thus, one notable feature of Darwin's moral view is its reliance on group, rather than individual, selection. Consider courage, for example. Darwin would want to say that courage (which we think is a virtue), is an evolved trait and the reason it evolved is its contribution to fitness. But, as Allhoff (2003, p.88) noted, whose fitness would this be?

How can natural selection produce altruistic individuals, since it basically enhances an individual's fitness and ensures their reproductive success? How could morally conscious and altruistically inclined individuals possibly emerge as the end products of so fierce a struggle for existence that Darwin has often talked about? Clearly, courage does not always contribute to the fitness of its possessor. Imagine that we have a society which exists in competition with other nearby societies, and therefore needs (courageous) soldiers for its protection. Allhoff (2003) put this dilemma in the following way: Imagine that we were to take two men, who were equal in all but one respect: the first had the courage to answer the call to defend his society, whereas the second did not and therefore chose another profession. It seems clear that the life expectancy of the soldier would be shorter than the life expectancy of the non-soldier. Therefore, courage would not make its possessor more fit (in terms of reproductive success), but rather less so. 
To wriggle out of this conundrum, Darwin claimed that those who lay down their lives would have left their trait in those who survived and for whom they laid down their lives, albeit unknown to either. This explanation persists among evolutionary theorists even for phenomena such as contemporary suicide bombing (Glausiusz 2003, par.2). Darwin (1871, 68f; added emphasis) summarily held that any animal species that lives in a group will inevitably develop or attain a moral sense due to a bonding that would have developed in that group:

[A]ny animal whatever, endowed with well-marked social instincts, would inevitably acquire a moral sense or conscience, as soon as its intellectual powers had become as well developed, or nearly as well developed, as in man.

Darwin also noted that, among certain animal populations, there exist some apparently useless traits, such as brightly colored bodily ornamentation and extravagantly developed tails, as in the peafowl, or the exaggerated horns of a stag, and the sensational colour combinations of most fishes. To Darwin, such traits are apparently useless since they cannot possibly serve the animals possessing them the usual purpose of the struggle for existence. In fact, they constitute grave a danger to the animal by making it readily conspicuous to predators. This phenomenon almost invariably influences the physical appearances - known as secondary sexual characters - of the males over several generations, and makes them rather physically attractive to females, in such a way that enables them to leave more offspring than others that are less endowed with such sound and sleek appearances. 
In Darwin's reckoning, this is a more fundamental phenomenon because natural selection cannot even get off the ground if animals did not breed and produce offspring through which they propagate their traits or characters into the future. Darwin (1871, p.248) expatiated:

... [T] hose individuals which generated or nourished their offspring best, would leave, ceteris paribus, the greatest number to inherit their superiority; while those which generated or nourished their offspring badly, would leave but few to inherit their weaker powers. As the male has to search for the female, he requires organs of sense and locomotion, but if these organs are necessary for the other purposes of life, as is generally the case, they will have been developed through natural selection.

In all, Darwin tended to think that sexual selection explains, for instance, not only the apparent useless differences between males and females, but also how the different human races could have arisen; for if sexual selection continued, as it did, over several generations, very divergent kinds of offspring will inadvertently emerge, in the long run (Endersby 2003).

\section{Evolution and Ethics: Later Developments}

It is one thing to give a biological account of morality, as Darwin had done, and another thing to draw normative conclusions from the account. In Principle of Ethics (1873), Herbert Spencer, the social scientist and philosopher, claimed that a bitter and brutal struggle for existence obtains as a biological fact within every ecosystem, in order to determine who survived and who was weeded out. Ideas like these that emanated from Spencer and those 
who would sympathise with his thesis became known as 'Social Darwinism', according to which Darwin's permutations on natural selection are taken to equally apply to human society (Netíková, 2019, p.4; Holmes and Livingstone, 2021, p.3). Spencer's (cited in Allhoff 2003, p.90) thinking on this issue is articulated in his disapproval of British poor laws:

[T] here is an habitual neglect of the fact that the quality of a society is lowered morally and intellectually, by the artificial preservation of those who are least able to take care of themselves...For if the unworthy are helped to increase, by shielding them from that mortality which their unworthiness would naturally entail, the effect is to produce, generation after generation, a greater unworthiness.

Although Spencer is often thought to be grossly misunderstood (for example, Holmes and Livingstone, 2021, p.3f), his unrelenting aversion to the poverty welfare of Victorian Britain certainly has not helped matters on the side of his numerous critics, who have deemed his ideas decidedly unethical. For instance, he unequivocally berated the poor in the following unsavory language: 'If they are not sufficiently complete to live, they die, and it is best they should die' (Spencer 1868, p.414; cited in Roark 2004, p.25). Elsewhere, Spencer (cited in Roark 2004, p.6) harshly attacked the advocates of liberal communitarianism, who presumably held views supporting poverty alleviation, describing them 'Spurious philanthropists ... blind to the fact that under the natural order of things society is constantly excreting its unhealthy, imbecile, slow, vacillating faithless members. He apparently thought that any attempt to aid the 'undeserving poor' only succeeds in putting off 
misery for future generations, which, according to him, is tantamount to fighting against nature, against the eternal struggle for existence, on the basis of which life can only advance or make progress.

Thomas Henry Huxley-a prominent evolutionary biologist and contemporary of Darwin, known as 'Darwin's Bulldog' — promptly attacked Spencer's ideas in a series of lectures (Romanes Lecture (1893) and Prolegomena to Evolution and Ethics (1894)) that later emerged as parts of his volume on Evolution and Ethics. Huxley contended that although evolutionary biology may fittingly render an account of how our moral tendencies may have evolved, its principles of operation could hardly be adopted in an actual human society, because in nature what obtains is a brutal struggle among organisms for survival, which is contrary to the ethical nature necessarily demanded of humans in society (Netíková, 2019). Besides, it is also true that the 'immoral sentiments' have no less been evolved, giving our moral and immoral tendencies an equal natural sanction. In fact, the ethical progress of society necessarily demands that humans must combat the cosmic process and its ruthless struggle for existence with their ethical nature. Evolutionary biology can never proffer a viable justification for why humans would prefer to choose good over evil.

Stephen (1993) disagreed with Huxley, in a paper titled 'Ethics and the Struggle for Existence'. He argued that Huxley's contentions are based on the tenuous assumption that the struggle for existence necessarily involves antagonism and 'internecine' hostilities, whereas, in fact, it does bring about cooperation among individuals in an ecosystem. According to Stephen (1893/1993, p.85): 
Every animal ... is absolutely dependent for a considerable part of its existence upon its parents. The young bird or beast could not grow up unless its mother took care of it for a certain period. There is, therefore, no struggle as between mother and progeny, but, on the contrary, the closest possible alliance. Otherwise life would be impossible.

The struggle for existence even engenders altruistic behaviour in species, in purely natural circumstances, especially if mutual benefit is at stake. For Stephen, natural selection simply has nothing moral or immoral about it, as it is merely how nature operates; and there is nothing anyone can do about it, no matter how (morally) repugnant it may appear to humans. Even then, it does not make sense to apply anthropomorphic attributes to the inferior animal species that do not even begin to understand such attributes. Hence, it does not matter to the individual sheep how it dies, whether by the wolf, disease or starvation: 'He has to die anyway, and the particular way is unimportant. The wolf is simply one of the limiting forces upon the sheep, and, if he were removed, others would come to play' (p.83f.).

In similar vein, Dewey (1898/1972) noted that Huxley's dualism failed to recognise the fact that all that happens in nature must be taken holistically. The same mechanism that propels the so-called 'cosmic process' also fosters the 'ethical process', like the two sides of the same coin, each of which ultimately has a part to play in accordance with the need of organisms in an ecosystem.

Moore's contribution to this debate set off the most ripples, determining the direction of much of 20th century metaethics in the English-speaking world. In Principia Ethica (1903), Moore devoted considerable attention to Spencer's views, stating that 
'good' was a simple (not constituted of parts), non-natural (not determinable or measurable by empirical means), indefinable property, whose presence may only be intuited. Based on his decidedly extreme Darwinian views, Spencer had erroneously believed that 'good' could be explained in purely natural terms as 'the greatest happiness' or, more specifically, 'maximal freedom for all', thinking that more information could be given about the nature of the term 'good' as used in moral thought. For Moore (1903, p.58), Spencer committed a naturalistic fallacy by identifying the notion of 'good' in terms of natural properties. To justify his position, Moore offers the 'open question argument'. If 'good' meant the same as 'promotes happiness', for example, the question 'I know that $x$ is good, but does $x$ promote happiness?' would be as nonsensical as asking 'I know Smith is a bachelor, but is he an unmarried male?' It is precisely because 'bachelor' means 'an unmarried male' that the second question is trivial. According to Moore, the reason that the first question does not share this triviality is because 'good' does not mean the same as 'promotes happiness' - since we can meaningfully ask whether the good promotes happiness, 'good' cannot be defined in terms of promoting happiness.

Moore is, on this count, believed to be influenced by Hume's (1740/2003, p.334) 'is/ought' distinction, which highlighted the illogic of moving from a set of purely factual premises to a normative conclusion in categorical syllogisms. In valid categorical syllogisms, since the conclusion is tacitly contained in the premises, direct transition from factual premises to a normative conclusion (due to the introduction of normative concepts) would, a fortiori, invalidate the argument, unless one of the premises is a normative proposition. 'Hume's Law', as it is known, was potentially violated by Spencer's ethical system, which 
Odozor and Akintona: Can Anything Philosophical Come out of Darwinism?

should, therefore, be rejected. After Moore's arguments, evolutionary ethics was literally abandoned until 1975, with the publication of Edward Wilson's Sociobiology: A New Synthesis.

\section{The Affinities between Evolutionary Biology and Philosophy}

Albeit, one area in which Darwin's work would bear on philosophy — even if implicitly — is, perhaps, on the metaphysical problem of God's existence, which philosophers and natural scientists alike had debated at length. But these debates did not culminate in a definite, alternative theory of the origin of reality that is systematic and, ipso facto, based on biological science. The discourse on the existence and nature of God was done on purely speculative grounds, especially in reference to the problem of evil (Hick 1994, p.39f.). The argument from evil was viewed as a decisive refutation of God's existence, or proof of his impotence. After two thousand years of this debate, Hume (1948, p.64) could still observed that:

Epicurus' old questions are yet unanswered. Is he [God] willing to prevent evil, but not able? Then is he impotent. Is he able, but not willing? Then is he malevolent. Is he both able and willing? Whence then is evil?

It was deemed inconceivable - against the Christian notion of a beneficent God - that a good God would have created a world in which evil was ubiquitous. But no one approached the issue from the point of view of species having spontaneously evolved into other forms, rather than being individually created, as the biblical Genesis account suggests. While some philosophers, such as Descartes and Kant, had thought that the phenomenon of (moral) 
perfection offers some evidence for God's existence (ChávezArvizo 1997, p.xviii), other research interests were driven in the direction that reached its peak with William Paley's (1802) famous argument for the existence of God from beauty, order and design. To this end, the theory of natural selection, at least, seemed to offer some sort of solution to this age-old philosophical quandary, and would, to that extent, be quite philosophically significant. Darwin proffered a purely scientific, alternative account of the origin of the cosmos, which not only competed favourably with other accounts, but also seems to explain why nature sometimes behaves in a mindless fashion. Yet Wittgenstein and the others would not recognise this fact, even when working in a philosophical epoch that in which the disavowal of metaphysics was the order of the day. Following Darwin, contemporary evolutionary theorists, such as Richards (1993, p.120), have argued for 'the logic of an ethical theory based on evolution'. For him, the legitimate question is whether the enterprise of evolutionary biologists makes sense logically, not whether evolution is philosophically relevant.

Be that as it may, objections of the above nature apparently have the far-fetched implication that philosophy and the natural sciences have rather little in common. But to what extent can the assumption that philosophy and the sciences do not have any common areas of interest be sustained? Does the fact that a particular insight has been derived from science automatically render it immune to philosophical investigation? A peek into the past experience suggests a rather different set of facts: history is replete with influential philosophers who were also accomplished natural scientists. Also, philosophers and natural scientists are known to have worked together in certain areas of common interest, such as Philosophy of Science. To gain comprehensive insight into a hitherto unknown area of human knowledge, scholars often 
explore it from the point of view of their respective disciplines and areas of specialisation. While scientists proffer their scientific explanation, philosophers would bring forward a philosophical examination and interpretation. So it is for the theologians and the social scientists, who would make their own contributions from the point of view of their respective disciplines, unless that issue has not really been able to elicit enough scholarly interest, or controversy. Jeans (1981, p.2) explains this interplay from the point of view of physics:

The philosophy of any period is always largely interwoven with the science of the period, so that any fundamental change in science must produce reactions in philosophy. This is especially so ... where the changes in physics itself are of a distinctly philosophical hue; a direct questioning of nature by experiment has shown the philosophical background hitherto assumed by physics to have been faulty. The necessary emendations have naturally affected the scientific basis of philosophy and, through it, our approach to the philosophical problems of everyday life.

Even if Darwin's theory is pure science, there would be nothing wrong in undertaking a philosophical exploration of his ideas, in as much as they purport to underscore some issues of philosophical interest.

Regardless of the suggestion that some aspects of Greek thought may be linked to Africa (Onyewuenyi 1987), closer look at Darwin's theory of evolution reveals a rough affinity to the fundamental questions that led the ancient Greeks to systematic philosophy. Though the Greeks used some doses of metaphysics, both Darwin and the Greeks raised, and attempted to proffer 
answers to, questions concerning the origin and nature of the physical world of experience. Darwin answered the question by pointing out that the generality of things in the world of experience, in all their complexities, including humans, were spontaneously generated from simple life forms. The ancient philosophers systematically argued their ways variously to Air, Water, Earth, Fire, or a combination of two or more of these basic elements (Copleston, 1993, pp.25ff). Darwin used experiments to arrive at his conclusions; so did the ancient Greeks, whose rudimentary procedures may appear naïve, or ridiculous, today simply because contemporary scholarship is privileged to be in possession of an immense wealth of knowledge and awareness that have been generated, tested and refined for over two and a half millenniums of rigorous research. We now take for granted immense deposit of knowledge to which the Greeks could not possibly be privy at that point in history, yet which has been engendered, or at least catalyzed, by their own work.

Nogar (1963, p.251) defined evolutionism as:

[The] pattern of thought and a way of life governed by the principle that the universe, composed of mater is ... motion, is in a continual state of evolution, that evolution accounts for the origin of all things, and [therefore] that nothing is absolutely fixed or immutable.

The philosophical correlates of the notions contained in this definition are easily derivable from the works of Heraclites and Parmenides, who attempted to proffer viable explanations for the phenomenon of change, with the former positing flux, in contrast to Parmenides' own permanence. Besides, the evolutionary notion in the above citation that "nothing is absolutely fixed or 
immutable" can pass for an unwitting attack against essentialisma major doctrine of Western philosophy for over two thousand years. If Darwin is right that reality is constantly undergoing transformation, albeit gradually, even if imperceptibly, then there would seem to be no reason for thinking that any aspect of reality is immutable, eternal, or fixed. As Hodge and Radick (2003, p.10) further explained:

[Evolutionary] laws entail variation over time and space in all species; and this variation implies-quite inconsistently with the essentialism of Plato or Aristotle, say-that no species, human or plant or animals, has any essential nature. Darwinism, in brief, made essentialism untenable.

Darwinism may also be interpreted as a reaction against the age-old Protagorean maxim that ' $m a n$ is the measure of all things, of the things that are, that they are, and of the things that are not, that they are not' (Stumpf 1994, p.32). Darwin attempted to dismantle the age-old philosophical notion that the human species is 'dignified' and separated from the rest of the animal kingdom, owing to the attributes of 'rationality' and 'moral consciousness' (Ayala and Arp 2010, p.294). Rather, Darwin demonstrated that the human is simply continuous with all other animal species, have descended from a common ancestry. This insight later served as theoretical framework for twentieth century animal liberation thought (Regan and Singer 1976).

Further, Darwin's findings are roughly parallel to Hobbes' social contract hypothesis, according to which primordial individuals learned from experience that their interests would be better served if they entered into some form of cooperative 
arrangement with others. Two hundred years earlier, Hobbes (1960) had speculated that the earliest human social and political organisations originated by way of a mutual agreement: people opted for government, with its attendant obligations, in order to avoid or escape a repugnant 'state of nature. So also do the ideas of conflict and its subsequent management, or resolution, occupy a central position in Darwin's theory. For Darwin, primordial humans were able to learn from experience that more would be achieved by cooperation and mutual aid, than by fighting; and this culminated in the evolution of moral sentiments, via social instincts, without which their corporate survival would be impossible. According to Darwin (1871, p.157):

In the first place, as the reasoning powers and foresight of the members became improved, each man would soon learn from experience that, if he aided his fellowmen, he would commonly receive aid in return. From this low motive he might acquire the habit of aiding his fellow men; and the habit of performing benevolent actions certainly strengthens the feeling of sympathy, which gives the first impulse to benevolent actions.

With its materialist or monist account of reality, Charles Darwin's work may, as well, be viewed as a rejection of the Platonic, the Cartesian, and, in fact, any form of, dualism. Had Darwin's theory referred only to plants and other lower animal species, things would probably be different, as little philosophical attention would likely have been accorded his insights, except, perhaps, in form of the kinds of issues discussed in the Philosophy of Nature. But the introduction of the human species into the evolutionary universe of discourse changed everything, as philosophers have, from time immemorial, been interested in 
understanding the human person and the world in which she lives. To this end, Young (1985, p.164) aptly described the evolutionary discourse of Victorian England as 'the debate on man's place in nature'.

What informed Wittgenstein's statement cited earlier is presumably his conception of the philosophical enterprise as the analysis of 'philosophically puzzling language' (Urmson 1956, p.vii). However, beyond this 'tool' idea of philosophy lies the equally (or more) important question of 'content' or subject matter of philosophy. For in as much as conceptual clarification is a veritable tool for doing philosophy, the subject matter of any philosophical work is not any less important to philosophers, as Popper (2002, p. xviii; original emphasis) has persuaded:

Language analysts believe that there are no genuine philosophical problems, or that the problems of philosophy, if any, are problems of linguistic usage, or of the meaning of words. I, however, believe that there is at least one philosophical problem in which all thinking men are interested. It is the problem of cosmology: the problem of understanding the worldincluding ourselves, and our knowledge, as part of the world. All science is cosmology, I believe, and for me the interest of philosophy, no less than of science, lies solely in the contributions which it has made to it. For me, at any rate, both philosophy and science would lose all their attraction if they were to give up that pursuit. Admittedly, understanding the functions of our language is an important part of it; but explaining away our problems as merely linguistic 'puzzles' is not. 
Given the staggering amount of philosophical (and philosophically significant) literature that has been generated in response to the evolutionary theory between the time Wittgenstein issued his earlier cited statement, 1922, and now, it would be wondered how his insinuations could actually come across as wellinformed. Although work on evolution was still beginning during Wittgenstein's time, substantial quantities of decidedly philosophical work have now been accumulated on evolution. Today, the Philosophy of Biology and Evolutionary Ethics have both become a force to reckon with, as clear expressions of the fact that the evolution theory has, indeed, so much to do with philosophy. Primatologist Frans de Waal (1996, p.218) rightly referred to this area of research as 'a budding field'. Darwinism has become established as a unique channel by which philosophy and science converge; according to Young (1985, p.235; original emphasis) it is 'the central conception linking humanity and social theory to natural science'. Thus, even prior to Wittgenstein, other philosophers such as Royce (1892, p.286) had reached the unalloyed conclusion that:

With the one exception of Newton's Principia no single book of empirical science has ever been of more importance to philosophy than [the] work of Darwin.

Keith (1955, p.37) was even more forthcoming, consolidating this viewpoint as follows:

Claims ... can be made for giving Darwin a place in the rank of philosophers. ... Darwin was an objective philosopher, the first of the kind. ... What other philosopher covered so wide a range of inquiry or reaped so great a harvest of knowledge? 
A more recent argument for the philosophical import of natural selection is that of Lewens (2007, p.262), who rejected absolute or replacement naturalism in philosophy:

Darwin's work is important to mainstream philosophy because Darwin demonstrates that the human capacities which interest philosophers - the ability to know, to think, to praise and condemn - have histories, and that they can be studied in the ways we might study the capacities of any other species. This does not entail an abandonment of abstract philosophical theorising, but it does point the way towards closer integration between philosophy and the natural sciences. Darwin's work is also important in a broader philosophical sense. It changes how we think of ourselves ... [and] does not show that our own species is the best the natural world has to offer ...

\section{Conclusion}

From the above analysis, it clear that evolution portends a great deal, not just for traditional moral philosophy, but also for philosophy as a whole. The past four decades has seen the resurgence of the effort, particularly in Western scholarship, to incorporate evolutionary considerations into our understanding of a wide range of phenomena. This has happened not just in philosophy, but across several fields of human inquiry, including psychology, politics, anthropology, epistemology, metaphysics, aesthetics, and religion. Similarly, it has been argued by evolutionary naturalists that ethical inquiry can only be meaningfully done within the ambits of biological science, in form 
of the supposedly viable alternative called evolutionary or biologicised ethics (Wilson 1975, p.562). This gave rise to the persuasion, which has been gaining ground in contemporary Western scholarship, that philosophical ethics should be abandoned, or, at best, treated as part of natural history (Curry 2005). Naturally, it leads to a further relevance of evolutionary biology, as seen in these philosophically interesting questions: To what extent does the notion that morality may have a biological facet render moral philosophy obsolete? Is there more to ethics and human morality than the biological approach allows? (Odozor and Metuonu 2011). As attempts are made to resolve these issues and due cognizance is taken of the contributions of evolutionary science to a better understanding of philosophical problems in particular, and the advancement of human knowledge in general, inquiry would ultimately yield a rigorously developed and well-articulated sub-field of 'evolutionary philosophy'.

Uche S. Odozor \& Emmanuel O. Akintona are of Philosophy Unit, Department of Communication and General Studies, Federal University of Agriculture, Abeokuta, ucheodozor@yahoo.com 
Odozor and Akintona: Can Anything Philosophical Come out of Darwinism?

\section{References}

Allhoff, F. (2003). 'Evolutionary Ethics from Darwin to Moore.' Hist. Phil. Life Sci. Vol.25, pp.83-111.

Ayala, F. J. and Arp, R. (Eds.). (2010). 'Introduction.' Contemporary Debates in Philosophy of Biology. Oxford: Blackwell. Pp.293-296.

Boniolo, G. and De Anna, G. (Eds.). (2006). Evolutionary Ethics and Contemporary Biology, New York: Cambridge University Press. Pp.1-10.

Browne, J. (2018). 'Charles Darwin and the Darwinian Tradition.' In M. Dietrich et al. (eds). Handbook of the Historiography of Biology. Springer International Publishing. 1-25. https://doi.org/10.1007/978-3-319-74456-8_4-1.

Chávez-Arvizo, E. (1997). 'Introduction.' In Chávez-Arvizo, E. (Ed.). Descartes: Key Philosophical Writings. London: Wordsworth.

Choi, C.Q. (Nov. 12, 2007). 'Double Trouble: What Really Killed the Dinosaurs.' Live Science. Retrieved Nov. 16, 2007, from

http://news.yahoo.com/s/livescience/20071112/sc_livescie nce/doubletroublewhatreallykilledthedinosaurs

Copleston, F. (1993). A History of Philosophy. Vol.I. New York: Doubleday.

Cunningham, S. (1996). Philosophy and the Darwinian Legacy. Rochester: University of Rochester. 
Curry, O. (2005). 'Morality as Natural History.' PhD Thesis. Government Department. University of London: LSE Research Online. Retrieved September 23, 2009, from http://eprints.lse.ac.uk/archive/00000441.

Darwin, C. (1871). The Descent of Man and Selection in Relation to Sex. New York: D. Appleton.

Darwin, C. (1859). On the Origin of Species by Natural Selection. London: Murray.

de Waal, F. (1996). Good Natured: The Origins of Right and Wrong in Humans and Other Animals. London: Harvard University Press.

Dewey, J. (1972). 'Evolution and Ethics.' In Boydston, J.A. (Ed.). The Early Works of John Dewey 1882 - 1898, 5 (18951898). 34-54 Carbondale and Edwardsville: Southern Illinois University Press. Originally published in The Monist, April 1898. Vol8. No.3, pp.321-341.

Endersby, J. (2003). 'Darwin on Generation, Pangenesis and Sexual Selection.' In Hodge, M.J.S. and Radick, G. (Eds.). The Cambridge Companion to Darwin. Cambridge: Cambridge University Press. 69-91.

Flew, A.G.N. (1967). Evolutionary Ethics. Hudson, W.D. (Ed). London: St. Martin's Press.

Glausiusz, J. (October 2003). 'The Surprises of Suicide Terrorism: It's Not a New Phenomenon, and Natural Selection May Play a Role in Producing It.' Discover. 24.10. Interview with Anthropologist Scott Atran. Discover Dialogue. Retrieved Nov. 11, 2005, from 
Odozor and Akintona: Can Anything Philosophical Come out of Darwinism?

http://www.discover.com/issues/oct-

03/departments/featdialogue/

Hick, J. (1994). Philosophy of Religion. 4th Ed. New Delhi: Prentice-Hall of India Private.

Hobbes, T. (1960). Leviathan. Oakshott, M. (Ed.). Oxford: Basil Blackwell.

Hodge, J. and Radick, G. (Eds). (2003). The Cambridge Companion to Darwin. Cambridge: Cambridge University Press.

Holmes, A.R. and Livingstone, D.N. (2021). 'Creation, Evolution, and "The New Cosmic Philosophy": William Todd Martin's Critique of Herbert Spencer.' Modern Intellectual History. $1-22$. https://doi.org/10.1017/S1479244321000056.

Hume, D. (1740/2003). A Treatise of Human Nature. New York: Dover.

Hume, D. (1948). Dialogues Concerning Natural Religion. Aiken, H. D. (Ed.). New York: Hafner.

Huxley, T. H. (1898). 'The Romanes Lecture.' In Evolution and Ethics and Other Essays. New York: D. Appleton.

Huxley, T. H. (March 23, 1894). 'Letter to Thomas Common.' In T.H. Huxley: Letters and Diary, 1894; Retrieved February 19 , 20011 from: http://aleph0.clarku.edu/huxley/letters/94.html\#16oct1894 prime. 
Huxley, T. H. (1888). 'The Struggle for Existence in Human Society.' Evolution and Ethics and Other Essays. New York: D. Appleton, 1896. 195-236.

Huxley, T. H. (1859). 'Time and Life: Mr. Darwin's Origin of species'.' Macmillan's Magazine. 142-148.

Jeans, J. (1981). Physics and Philosophy. New York: Dover. [Originally co-published in 1943 by Cambridge University Press and the Macmillan Company].

Keith, A. (1955), 'Darwin's Place among Philosophers.' In Hawton, H. (Ed.). The Rationalist Annual. London: Watts.

Kingston, R.I. (November 17, 2004). 'URI Researcher Shows that Dinosaur Extinction Occurred at Peak of Diversity.' Science Daily. Dec. 2, 2004.

Lacey, A.R. (1976). A Dictionary of Philosophy. London: Routledge and Kegan Paul.

Lewens, T. (2007). Darwin. New York: Routledge.

Moore, G.E. (1966). Lectures on Philosophy. Lewy, C. (Ed.), London: Allen \& Unwin.

Netíková, K. (2019). 'T. H. Huxley's Evolution and Ethics: Struggle for Survival and Society.' E-LOGOS - Electronic Journal for Philosophy. 26(1) 4-18. DOI 10.18267/j.e$\log 0$. 460 .

Nogar, R. J. (1963). The Wisdom of Evolution. New York: Doubleday \& Company. 
Odozor and Akintona: Can Anything Philosophical Come out of Darwinism?

Odozor, U. S. and Metuonu, I. (September, 2011) 'Evolutionary Biology and the Determinants of Morality.' In Uduigwomen, A. F. (Ed.). Sophia: An African Journal of Philosophy and Public Affairs. Vol.13; No.2, pp18-26.

Onyewuenyi, I. C. (1987). African Origin of Greek Philosophy. Nsukka: Department of Philosophy, UNN.

Paley, W. (1802/2006). Natural Theology. Eddy, M.D. \& Knight, D. (Eds.). New York: Oxford University Press.

Popper, K. (2002). The Logic of Scientific Discovery. London and New York: Routledge.

Quammen, D. and Clark, R. (November 2004). ‘Darwin's Big Idea: Was Darwin Wrong?' National Geographic. 206.5: 2-35.

Rachels, J. (2003). The Elements of Moral Philosophy. New York: McGraw-Hill Inc.

Regan, T. and Singer, P. (1976). Animal Rights and Human Obligations. Englewood Cliffs, N.J.: Prentice-Hall.

Richards, R.J. (1993). 'Birth, Death, and Resurrection of Evolutionary Ethics.' Evolutionary Ethics. Nitecki, M.H. \& Nitecki, D.V. (Eds.). New York: State University of New York Press.113-132.

Roark, E. (2004). 'Herbert Spencer's Evolutionary Individualism.' Quarterly Journal of Ideology. Vol.27 No.3/4: 1-31. Retrieved Feb. 2010, from http://www.lsus.edu/la/journals/ideology/contents/vol27_3 4/eric_roark_herbert_spencer.pdf 
Royce, J. (1892). The Spirit of Modern Philosophy. New York: Houghton Mifflin.

Ruse, M. and Richards, R. (2017). 'Introduction.' In Richards, R. and Ruse, M. (eds.). The Cambridge Handbook of Evolutionary Ethics. Cambridge University Press. 1-9.

Russell, B. (1914). Our Knowledge of the External World. London: George Allen \& Unwin.

Schneewind, J. (1977). Sidgwick's Ethics and Victorian Moral Philosophy. Oxford: Clarendon.

Shkolenko, Y. (1987). The Space Age. Moscow: Progress.

Stephen, L. (1993). 'Ethics and the Struggle for Existence.' Evolutionary Ethics. Nitecki, M.H. \& Nitecki, D.V. (Eds.). New York: State University of New York Press, 81-94. Reprinted from The Contemporary Review. (August 1893); 64: $157-170$.

Stumpf, S.E. (1994). Philosophy: History and Problems. 5th ed. New York: McGraw-Hill.

Urmson, J.O. (1956). Philosophical Analysis: Its Development between the Two World Wars. Oxford: Clarendon Press.

Wilson, E.O. (1975). Sociobiology: A New Synthesis. Massachusetts: Harvard University Press.

Wittgenstein, L. (1923). Tractatus Logico-Philosophicus, London: Routledge \& Kegan Paul.

Young, R. M. (1985). Darwin's Metaphor: Nature's Place in Victorian Culture. Cambridge: Cambridge University Press. 